research councils for its allocation of public money, parcels out what it has to spend among a number of separate baronies responsible for research in different fields - astronomy, nuclear physics and so on. Democracy by committee being what it is, the result is that only marginal changes can be accomplished from one year to the next in the general pattern of spending.

But how else to deal fairly with a torrent of research grant applications when funds are short? The catch implicit in that reasonable question is that the members of the network of cheeseparing committees allow their sense of fair play to show as caution when the budget is tight, with the result that they back dull projects more often than they should. Sticking pins in a list of research grant applications would not suit either. On the startagain recipe, the research councils would instead follow different strategies, spending part of their funds with universities or university departments which had performed well in the past, sometimes inviting bids for research support in fields likely to have promise and conducting much more of their business in ways that would engage interested sections of the scientific community in decisions about what should be done. All these stratagems could of course give great offence, partly because they would constitute a departure from what has always been done, partly because they would seem less fair and, paradoxically, too open at the same time.

But is it not dangerous to acknowledge, when faced with pressure, obscurantism or even ignorance from above, that steps could be taken to improve the administration of the research enterprise? Only if the managers of the enterprise are not clear what they want to do with it. Now, there should be no doubt in anybody's mind - the tenor of British basic research needs to be strengthened, and effective steps need to be taken to see that the money being spent yields a substantial practical benefit. The British Government has given the research councils a licence to pursue the first goal, and keeps reminding everybody of the second.

The obvious difficulty is that none of the research councils nor their supervisory body, the Advisory Board for the Research Councils, is properly constituted for the pursuit of long-term objectives. Because of the inertia of the committees with which all are lumbered, clarity of purpose is rarely possible, but because both committee members and full-time officials play musical chairs with each other, continuity is equally elusive. (Sir James Gowans, secretary of the Medical Research Council, has nevertheless just been appointed for a second five-year term.) The result is almost the antithesis of leadership. New people arrive, seek to make their mark, start up some new programme which costs little at the beginning - and in the process lumber their successors with a range of expensive projects not fully understood. For a nation as obsessed as the British have been for three decades with the contemplation of the administration of research, it is astonishing that they have been so luckless at devising a strategy.

The remedy is simpler than it seems, but unfashionable. In the peculiar constitutional circumstances of Britain, the only means that has been found of combining policy with persistence is political. If there is a minister in charge of something, even the administration of bird sanctuaries, he will sooner or later be required to make a policy statement on the subject and that policy will be public policy until a successor makes a different public statement. Such a system could be operated on behalf of British basic science even as things are, for there is a minister (Sir Keith Joseph) with a bureacracy to support him (the Department of Education and Science). But quite apart from the minister's obvious disaffection from the task, the department is unsuitable. The science budget has always been peripheral to its main business, the continual reorganization of schools and school systems. Especially because the need for a seemly coordination of what is done on behalf of civil science with what other government departments do in competition has been made more urgent by the latest crisis, the time has come to revive the arrangement briefly (and successfully) relied on in the early 1960s - a part-time minister, a small bureaucracy and some open discussion of what should be done.

\section{What limits for coal?}

\section{The neglect of coal is proof that coalmining is a dirty job whose cost makes the product dear.}

WHEN people used to talk, in the early 1970 s, of the physical limits that would eventually halt economic growth, perhaps catastrophically, it was customary to cite materials such as tungsten or lead as examples of resources that were undeniably finite. The gloomy prophecies of those now-distant times are chiefly memorable for their failure to predict that an insubstantial circumstance such as a paper increase of the price of oil would do the same trick, and much more quickly, but they were also a rich source of prognostication about the future supply of energy in advanced societies. Briefly, the argument used to go, petroleum (the chief fuel of the 1960s) was a diminishing resource destined to become scarce and expensive in the then foreseeable future, perhaps in fifty years, certainly within a century. And since there were objections to the widespread use of nuclear power apart from the physical shortage of uranium, and because of the world's shocking neglect of resources such as solar energy (now called "renewables"), there would be an uneasy period in the future when it would be necessary for people to rely on coal as the chief fuel. Thankfully, most prophets would remark that there were at least ample reserves of coal still to be extracted from the Earth's crust.

So what is to be made of the present trouble in the British coal industry, where annual coal production has fallen steadily since the 1970s, where the labour force has declined even faster (because productivity has increased) and where a third of the labour force was on strike last week in protest at the industry's plan to reduce output still further, by 4 million tonnes from last year's output of 98 million tonnes? There is nothing wrong with the simple arithmetic of the old forecasts. Britain, which has been winning more than 100 million tonnes of petroleum from oil fields in the North Sea for more than the past decade, will soon see this windfall resource begin to tail off; production from the fields now being worked will be declining in aggregate before the end of the 1980s. And while there is no prospect that nuclear power will take up the slack, reasonable people might think that coal would be in demand again. Yet the opposite is true.

The explanation of the unexpected neglect of coal in the past decade is primarily the recession caused originally by the increased price of oil but which now also owes much to the permanent improvement of fuel efficiency to industry, commerce and in domestic usage. Those who constantly cry for what they call a fuel policy - by which they mean a set of explicit targets specifying the quantities of different kinds of fuels that will be used at different times in the future - should reflect that there has hardly ever been a better example of how usage will find a natural balance under the influence of market forces. The high cost of fuel has done more for fuel efficiency than any exhortation.

In Britain, however, there has been another uncomfortable economic influence at work - the unwillingness of coalminers to allow their employers to close down coal-pits operating at a loss. The result is that the coal industry will this year make a loss of more than $£ 200$ million even after counting the cost of public subsidies for stockpiling unsaleable coal, for not importing cheaper coal from elsewhere and for the social costs of uneconomic operations. The miners' chief argument, that it is somehow morally wrong to walk away from coal deposits that could be worked but only at high cost, resembles the old argument about the limits to growth in that it ignores economic costs. In present circumstances, the argument threatens to bring about a further and needless reduction of output. But for the long run, the dispute has a more sinister meaning, for it implies what most people will acknowledge to be true - that coalmining is such an unwanted and relatively ill-rewarded occupation that the cost of getting people to do it will always increase to the point at which coal is as expensive as any other fuel on the market. So the huge reserves of coal may be less useful than they used to seem. 